\title{
COMPARISON OF EFFECTS OF IONTOPHORESIS AND LOCAL INJECTION OF DEXAMETHASONE PHOSPHATE IN THE TREATMENT OF TENNIS ELBOW
}

\author{
Ahmed A. Ahmed ${ }^{1}$ \\ Raed S. Al-Naemi, ${ }^{2}$ \\ (Received : 7 December 2009 ---- Accepted : 20 December 2010)
}

\begin{abstract}
$\underline{\text { Abstract }}$
Background: Tennis elbow is the commonest example of traumatic tendon disease of the elbow; the causes may be due to the repeated stress, which could come from motions in sport or at work. The patients may complain of ache in the area that is present at rest or at night after activity. Different treatments as iontophoresis, ultra sounds, post isometric contraction relaxation and advice concerning in a proprial use of the hand extensors muscle.

Aim: to evaluate the most beneficial of the previously mentioned treatments in tennis elbow patients.

Patients and Methods: thirty six patients (25males and 11 females), most of them are nonathletic $(83.3 \%)$, their age range from $22-56$ years (mean value $=35 \pm 110$ ), who were clinically diagnosed as tennis elbow by an orthopedician or physiotherapy seniors. They were referred to the physiotherapy unit at Azadi hospital in Duhok city, Kurdistan region, republic of Iraq. The study period was dated from 1st March 2007 to $1^{\text {st }}$ April 2009; the patients were divided into two groups, group A (18 patients) treated with local Dexamethasone Phosphate injection (4mg), group B (18patients) treated with Dexamethasone Phosphate iontophoresis $(4 \mathrm{mg}$ ), the follow up of the patients was started after the initiation of treatments by one week and monthly continuo for 6 months.
\end{abstract}

Results: Patients in group A and B showed good response to local Dexamethasone Phosphate injection and Dexamethasone Phosphate iontophoresis $94.4 \%$ and $88.9 \%$ respectively. While $5.6 \%$ and $11.1 \%$ of the patients did not respond to the same treatment regime in group A and group B and they need surgical interference.

Conclusions: Iontophoresis is not superior to local injection with Dexamethasone, but it is preferable for their characteristics, as being non-invasive, non traumatic, less painful and safe technique.

Key words: Tennis elbow, Lateral epicondylitis, lateral epicondylalgia, iontophoresis, local injection.

\footnotetext{
${ }^{1}$ Lecturer,MSc Medical Physiology, Department of pharmacy,Duhok Technical Institute, Foundation of Technical Education/Erbil.Duhok,Iraq

${ }^{2}$ Assistant Professor, PhD Medical Physiology, Department of Medical Physiology ,Duhok Medical College of Medicine, Duhok,Iraq.
} 


\section{مقارنة بين تأثير ايونتمفوريسس والزرق الموضعي لكادة ديكساميثازون فوسفيت في ممالجة همرفق تنس \\ م م.د. احمد افل احمد \\ أ.م.د. أ. ائد سالم النعيمي

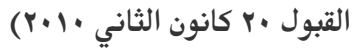

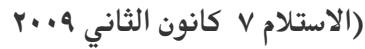

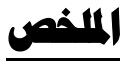

الخلقية: إصابة مرفق تتس من الأمثلة الثائعة لإصابات أوتار المرفق،وقد تكون سببها شد متكرر حاصل من

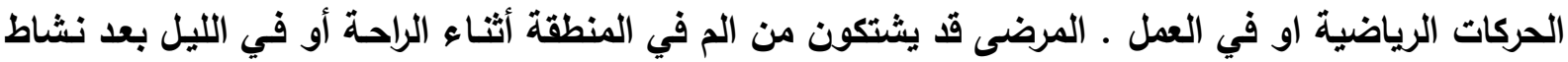

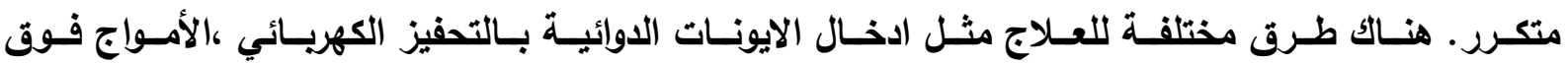

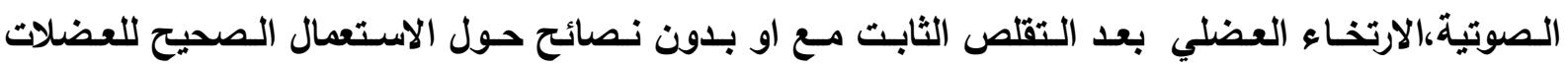

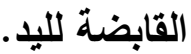

الهيف: يهدف البحث تقييم فعالية طريقتي العلاج الأكثر استفادة من طرق العلاج المذكورة سـابقا لمرضى مرفق التس.

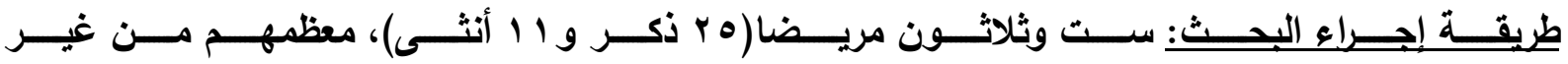

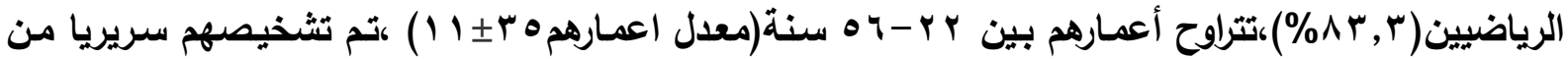
قبل أطباء العظام والكسور أو أخصائي العلاج الطبيعي. أحيلوا إلى وحدة العلاج الطبيعي في مستشفى ئازادى

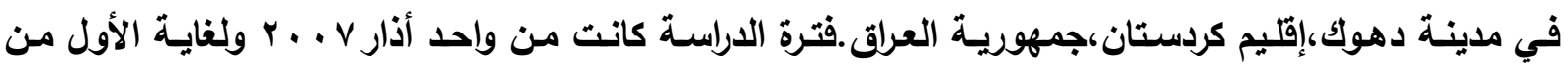

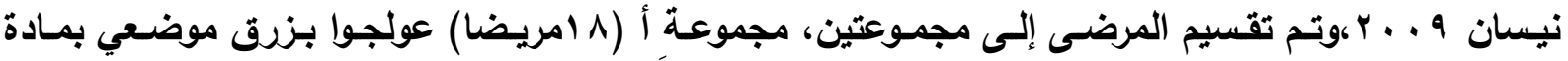

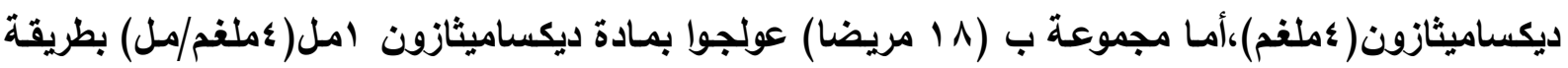

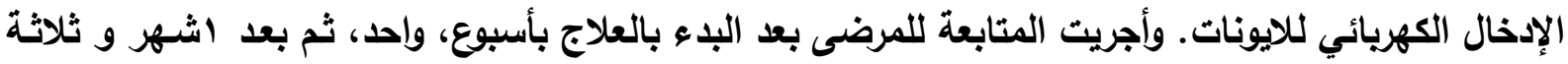

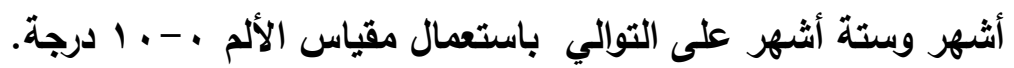

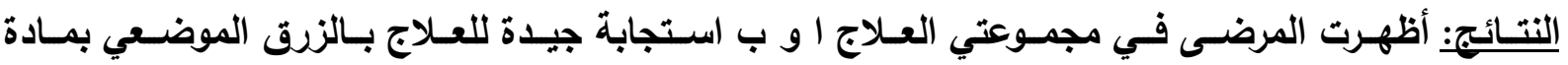

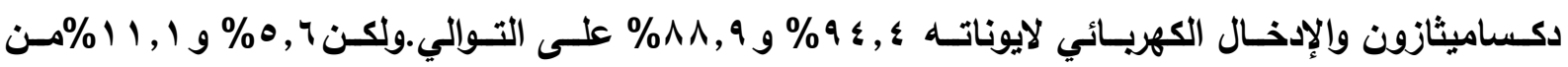
المرضى لم يستجييوا لنفس العلاج أعلاه على التوالي واحتاجوا إلى تداخل جراحي.

الاستتتاجات: لأتفوق لطريقة الإذخال الكهريائي للايونات عن الزرق الموضعي لمادة الديكساميثازون، ولكنه تفضل بسبب خصائصها الايجابية مثل كونها غير مؤذية أو مجرحة ويدون ألم وتقتية أمينة. 


\section{INTRODUCTION}

ennis elbow is the commonest name for the inflammation of the tendons(Tendonitis) attached to lateral, or outside, of the elbow at the bony bump of the humerus (upper arm bone).The medical term for this bony prominence is called

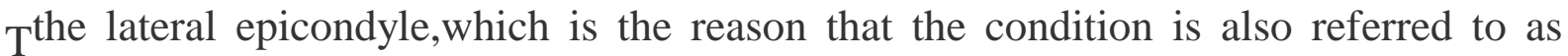
'lateral epicondylalgia',The condition is not limited to tennis players; it may develop as a sequel of local injury as well as to any activity that involve the forearm extensor muscles.

The pain is felt during grasping activities and may be accompanied by a feeling of weakness. Different treatments of tennis elbow are present including, local injection of corticosteroids, deep heat thearapy,ultra sounds, post isometric contraction relaxation and advice concerning in a proprial use[1,2,3].

The pain of tennis elbow may extend into the forearm and it is exacerbated by actions which stretch the ligamentous attachment of the forearm muscles to the lateral epicondyle.

This can be tested either by placing the patients arm in the waiter's tip position (i.e. elbow fully extended, forearm pronated and wrist flexed) and then ask the patient to try to extend their fingers against resistance. This will exacerbate the pain at the extensor insertion or by asking the patient to grip tightly with the hand while the elbow is fully extended and then with the elbow partly flexed.

If tennis elbow is present the first maneuver will be painful and the second much less so or not at all. If the problem is severe, the patient may have difficulty in extending the elbow even without clenching the hand[4].

Iontophoresis involves the movement of ions across biological membranes by means of an electric current for therapeutic purposes. The effect of any drug introduced by steroid injection was more effective than extracorporeal shock wave therapy[6].

High recurrence rates have been reported with corticosteroid injection, a common conservative treatment of tennis elbow. In a recent randomized controlled trial, $72 \%$ of patients reported recurrence of their condition within 12 months of receiving corticosteroid injection in comparison with $9 \%$ with a "wait and see" policy. It has been estimated that 5-10\% of patients develop chronic symptoms and eventually underwent surgical intervention $[7,8,9,10]$.

Iontophoresis is likely to be either local on the skin under the active electrode or systemic, because when the drug enters into the tissue fluids, it is disseminated throughout the body tissues. Iontophoresis using corticosteroids is a fairly new method recommended in the treatment of tennis elbow and has become popular owing to the impression of superiority compared with local injection, it is non-invasive, painless and non-traumatic[5]. 
This study was conducted to evaluate the effectiveness of Dexamethasone given locally or by iontophoresis in patients living in Duhok city area.

\section{Patient and methods}

This study was conducted from $1^{\text {st }}$ March 2007 to $1^{\text {st }}$ April 2009 on thirty six verbally consenting patients, after approval of scientific committee of the department of pharmacy, Duhok Technical Institute, Foundation of Technical Education, Duhok , Iraq. $\quad 70.4 \%$ of the patients are males $(n=25)$ and $29.6 \%$ are females $(n=11)$, most of them are non athletes $(83.3 \%$ ), their age ranged from 22 to 56 (mean $\pm \mathrm{SD} ; 35 \pm$ 11) ,with clinical diagnosis of Tennis Elbow. The exclusive criteria were tennis elbow patients have the disease with out any treatment apart from analgesia for the last three months. Randomly the patients were divided into two groups (A and B) alternatively, 18 patients each. Patients in group A were treated with single local injection of a mixture of [Dexamethasone phosphate (Natural Pharma Holdings Limited- LondonUK) $1 \mathrm{ml}(4 \mathrm{mg} / \mathrm{ml})$ with $1 \mathrm{ml}$ of xylocain $2 \%$ solution] using $2 \mathrm{ml}$ disposable syringe, while patients in group B were treated with same preparation by iontophoresis technique using electrical stimulator machine (type Endomed 982).

Pain grading was recorded according to the $0-10$ numeric rating scale $\quad(0=$ no pain, $1-3=$ mild pain, $4-6=$ moderate and $7-10=$ sever pain) before treatment and after one week, one, three and six months. For statistical study by using SPSS program 18 (2009), we were used unpaired T-test in order to compare between each degree of pain of both groups and Kruskal Wallis Test (H-Test) to compare within each group the $4^{\text {th }}$ degrees of pain scale and it values after that during the 4 follow up times[13,14].

\section{RESULTS}

Insignificant differences $(\mathrm{P}>0.05)$ were found of the unpaired T-test results for comparison between each degree of pain between patients of group A and group B. Table one shows the classification of patients according to pain scale in group $\mathrm{A}$, which include (18 patients), three (16.6\%), eight $(44.4 \%)$ and seven $(39 \%)$ of the patients had mild, moderate and severe pain respectively prior to treatment. The follow up study shows the number of patients after one week, one, three and six months of local injection with Dexamethasone and xylocain to the site of the most tenderness (lateral epicondyle) with the advice not to put the extensor muscles of the wrist in action and with massaging the muscles above and below the point of tenderness. Our study shows that only one patient $(5.6 \%)$ of the patients in group A, not respond to the treatment and need surgical interference.

Table two shows the classification of patients according to pain scale in group B,which include (18 patients),four( 22.2\%),six( 33.4\%)and eight(44.4\%) of the patients had mild(grad 1-3), moderate(grade 4-6) and severe pain(grad 7-10) respectively prior to treatment. The follow up study shows the number of patients after one week, one, three and six months of the treatment with Dexamethasone phosphate and xylocain iontophoresis to the site of the most tenderness (lateral epicondyle) with 
the advice not to put the extensor muscles of the wrist in action and with massaging the muscles above and below the point of tenderness. Our study shows that only two patients $(11.1 \%)$ of the patients in group B not respond to the treatment and need surgical interference, while statistical study showed insignificant difference between both group $(\mathrm{P}>0.5)$.

\section{DISCUSSION}

The results of the present study postulated that tennis elbow was recorded also in non-athletic subjects, although our sample is small (36patients) but it shows that it is more common among male patients $(69.4 \%)$ than in female patients $(30.6 \%)$, and it occurred more at middle aged patients $(35 \pm 11)$ years. the same finding was recorded previously by Kivi (1983), who found that, $56.8 \%$ of the patients were male and the mean age group was 43years.

In the present study $17(94.4 \%)$ of the patient showed an excellent response to the local injection versus $16(88.9 \%)$ which responded to iontophoresis, i.e no significant difference between both methods, and this goes with that showed by the Kivi study (1983) and the result of the Runeson and Haker (2002) which not encouraging to use corticosteroid iontophoresis in lateral epicondylalgia, however, in this study we found that $16(88.9 \%)$ of the patients had a good response after six month of treatment with Dexamethasone iontophoresis.

These results indicate that local Dexamethasone injection seems to be superior to iontophoresis treatment; although the corticosteroid iontophoresis is preferable because of its safety, non-invasive, less painful and easy technique.

\section{References}

1. Robert B. Salter; Text book of diseases and injuries of the musculo- skeletal system. $2^{\text {nd }}$ edition, Williams and Wilkins, (1983). 11: 245.

2. Haslett C.,Chilvers E.,Hunter J.,Boon N.(1999) Davidson's principles and practice of medicine (18 ${ }^{\text {th }}$ ed.). UK: Churchill Livingstone. $12 ; 825$.

3. Lewit K. (1991) Manipulative therapy in rehabilitation of the locomotors system $.2^{\text {nd }}$ edition.Oxford.Butterworth. 6; 201-202.

4. Munro J., Edwards C. (1995) Macleod's Clinical Examination.9 ${ }^{\text {th }}$ edition. New York and Tokyo. Churchill Livingstone. 9;296-297.

5. Ahmed A. (2006) Iontophoresis as a technique for carpal tunnel syndrome treatment.J.Dohuk Univ.,.9;.1, 133.

6. Buchbinder R. Green S. Yo ud JM. Assendelft WJJ.Barnsley L.and Smidt N. (2006)Systematic review of the efficacy and safety of shock wave therapy for lateral elbow pain. J Rheumatol ; 33:1351-63.

7. Boyd HB, McLeod AC. Tennis elbow. J Bone Joint Surg Am 1973; 55:1183-7.

8. Conrad RW, Hooper WR. Tennis elbow: its course, natural history, conservative and surgical management. J Bone Joint Surg Am 1973; 55:1177-82. 
9. Baker CL, Murphy KP, Gottlob CA, et al.. Arthroscopic classification and treatment of lateral epicondylitis: two-year clinical results. J Shoulder Elbow Surg 2000; 9:475-82.

10. Nirschl RP, Pettrone FA. Tennis elbow. The surgical treatment of lateral epicondylitis. J Bone Joint Surg Am 1979; 61:832-9.

11. Runeson L, Haker E. Iontophoresis with cortisone in the treatment of lateral epicondylagia (tennis elbow)-a double-blind study. Scand J Med Sci Sports. 2002 Jun; 12: 3,136-42.

12. Kivi P. The etiology and conservative treatment of humeral epicondylitis. Scand J Rehabil Med. 1983; 15:1,37-41.

13. Enraf-Nonius B.V. Endomed 982 operating instruction.2000.p23-40.

ـ ا ـمحد بلال الزغبي و عباس الطلاحفة. النظام الاحصائي ( SPSS )فه وتحليل البيانات الاحصائية.الطبعة

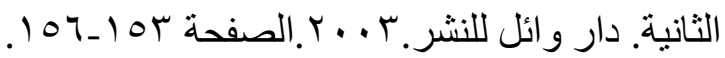

Table 1: The number and percentages of the patients in group A before and after treatment with single local injection of a mixture of Dexamethasone and xylocain grading according to the degree of pain in follow up study

\begin{tabular}{|c|c|c|c|c|c|}
\hline \multirow[t]{2}{*}{ Group A } & \multirow{2}{*}{$\begin{array}{l}\text { Before } \\
\text { treatment }\end{array}$} & \multicolumn{4}{|c|}{ Follow up after treatment } \\
\hline & & 1 week & 1month & 3month & 6month \\
\hline No pain (0) & $\begin{array}{c}0 \\
(0 \%)\end{array}$ & $\begin{array}{c}8 \\
(44.4 \%)\end{array}$ & $\begin{array}{c}13 \\
(72.2 \%)\end{array}$ & $\begin{array}{c}15 \\
(83.3 \%)\end{array}$ & $\begin{array}{c}17 \\
(94.4 \%)\end{array}$ \\
\hline $\begin{array}{c}\text { Mild pain } \\
(\mathbf{1}, \mathbf{2 , 3})\end{array}$ & $\begin{array}{c}3 \\
(16.7 \%)\end{array}$ & $\begin{array}{c}1 \\
(5.6 \%) \\
\end{array}$ & $\begin{array}{c}0 \\
(0 \%) \\
\end{array}$ & $\begin{array}{c}0 \\
(0 \%) \\
\end{array}$ & $\begin{array}{c}0 \\
(0 \%) \\
\end{array}$ \\
\hline $\begin{array}{c}\text { Moderate Pain } \\
(4,5,6)\end{array}$ & $\begin{array}{c}8 \\
(44.4 \%)\end{array}$ & $\begin{array}{c}4 \\
(22.2 \%)\end{array}$ & $\begin{array}{c}2 \\
(11.1 \%)\end{array}$ & $\begin{array}{c}1 \\
(5.6 \%)\end{array}$ & $\begin{array}{c}0 \\
(0 \%)\end{array}$ \\
\hline $\begin{array}{c}\text { Sever pain } \\
(\mathbf{7 , 8 , 9 , 1 0 )}\end{array}$ & $\begin{array}{c}7 \\
(38.9 \%)\end{array}$ & $\begin{array}{c}5 \\
(27.8 \%)\end{array}$ & $\begin{array}{c}3 \\
(16.7 \%)\end{array}$ & $\begin{array}{c}2 \\
(11.1 \%)\end{array}$ & $\begin{array}{c}1 \\
(5.6 \%)\end{array}$ \\
\hline
\end{tabular}

P>0.86(nonsignificant) of Kruskal Wallis Test( H-Test)

Table 2: The number and percentages of the patients in group A before and after treatment with a mixture of Dexamethasone and xylocain iontophoresis grading according to the degree of pain in follow up study 
COMPARISON OF EFFECTS OF IONTOPHORESIS AND LOCAL

\begin{tabular}{|c|c|c|c|c|c|}
\hline Group B & \multirow{2}{*}{ Before } & \multicolumn{4}{|c|}{ Follow up after treatment } \\
\cline { 3 - 6 } Pain scale & \multirow{2}{*}{ treatment } & $\mathbf{1}$ week & 1month & 3month & 6month \\
\cline { 3 - 6 } & & & & & 16 \\
\hline No pain (0) & 0 & 7 & 11 & 14 & 16 \\
& $(0 \%)$ & $(38.9 \%)$ & $(61.1 \%)$ & $(77.7 \%)$ & $(88.9 \%)$ \\
\hline $\begin{array}{c}\text { Mild pain } \\
(\mathbf{1 , 2 , 3 )}\end{array}$ & 4 & 3 & 1 & 0 & 0 \\
\hline $\begin{array}{c}\text { Moderate Pain } \\
(\mathbf{4 , 5 , 6 )}\end{array}$ & $(22.2 \%)$ & $(16.7 \%)$ & $(5.6 \%)$ & $(0 \%)$ & $(0 \%)$ \\
\hline $\begin{array}{c}\text { Sever pain } \\
(\mathbf{7 , 8 , 9 , 1 0 )}\end{array}$ & $(33.4 \%)$ & $(16.7 \%)$ & $(11.1 \%)$ & $(5.6 \%)$ & 0 \\
\hline & $(44.4 \%)$ & 5 & 4 & 3 & 2 \\
\hline
\end{tabular}

$\mathrm{P}>0.87$ (nonsignificant) of Kruskal Wallis Test( H-Test) 